\title{
Can Financial Ratios Reliably Measure the Performance of Banks in Bahrain?
}

\author{
Naser J. Najjar ${ }^{1}$ \\ ${ }^{1}$ College of Business Administration, Kingdom University, Manama, Bahrain \\ Correspondence: Naser J. Najjar, College of Business Administration, Kingdom University, Manama, Bahrain. \\ Tel: 97-33-683-3091. E-mail: najjarnaser@hotmail.com
}

Received: January 7, 2013

Accepted: January 21, $2013 \quad$ Online Published: February 22, 2013

doi:10.5539/ijef.v5n3p152

URL: http://dx.doi.org/10.5539/ijef.v5n3p152

\begin{abstract}
The aim of this study is to analyze the financial performance of major banks in Bahrain. This study covers the calculation of important financial ratios of major financial institutions in Bahrain as well as comparing their performance in the context of the global financial crisis. It also compares ratios of conventional banks with Islamic financial institutions in Bahrain. These ratios define profitability, financial performance, size and type of banks.

The analysis of ratios shows the differences in financial management practices of banks in the respective areas. The study reveals that there are wide differences in the ratios used by different banks, especially before and after the financial crisis.

This study helps identify best practice in the areas of profitability management, liquidity management, and interest rate risk management.

The result of the analysis of ratios for measuring financial performance shows that there is corporate excellence in asset management and value equity shares. This analysis can be used as a basis for preventative actions for future bankruptcy and market risk. The components in financial statements for Islamic banks differ from conventional banks.

The study recommends that banking institutions in Bahrain should use this ratio analysis to prevent unpredicted financial problems and take corrective measures or provisions to avoid such events for financial institutions.
\end{abstract}

Keywords: Central Bank of Bahrain (CBB), conventional banks, islamic banks, financial ratios, liquidity

\section{Introduction}

This study compares the performance of a group of banks in the Kingdom of Bahrain, depending mostly on their published financial statements and applying certain financial ratios as an indicator of financial management and evaluating financial performance.

\subsection{Issue of the Study}

The purpose of this work is to provide a new interpretation for financial ratios and how they can help analysts evaluate the overall financial condition of banks and organizations.

It will calculate and compare the important financial ratios used by major commercial banks as part of the financial management practices in the Kingdom of Bahrain.

This study highlights the performance of Islamic banks in comparison to conventional banks- as a result the findings are more applicable to the market in Bahrain.

\subsection{Objectives and Scope of the Study}

The objective of this study is to understand and analyze the different financial ratios which quantify many aspects of a banking business in Bahrain, by making comparisons between different types and size of banking institutions and comparing different time periods for a bank particular bank.

This analysis is primarily used to compare financial figures of banks over a period of time, a method sometimes called trend analysis. Through trend analysis, it is easy to identify positive and negative trends, and to adjust business practices accordingly. 
There are several limitations in this study when comparing ratios from one financial period to another or when comparing the financial ratios of two or more banking institutions

-If we are making a comparative analysis of a company's financial statements over a certain period of time, there should be a study of any changes in accounting policies that occurred during the same time span.

-When comparing business with the industry, there should also be an analysis of material differences in accounting policies between one company and industry norms.

-When comparing ratios from various fiscal periods or between different accounting methods, results may vary widely in reported figures.

-Determination of the nature of adjustments is another limitation. In many cases, these adjustments can significantly affect the ratios, whether ratios are calculated before or after adjustments are made to the balance sheet or income statement, such as non-recurring items and inventory or pro forma adjustments.

- Carefully examine any departures from industry norms.

\subsection{Significance of the Study}

This study will support both Islamic and conventional banks to understand the nature and operation of financial performance of banks in general, as well as enabling them to benchmark themselves with the sample taken for the purpose of this study.

\subsection{Research Questions}

- What are the ratios which can indicate the factors associated with high financial performance?

- Does the size of the bank determine the ratios used?

- What is the impact of financial ratios in indicating future performance management?

- Is there a significant difference between ratios applied for Islamic banks and those used for conventional banks?

- Is there a difference in performance measured by ratios before and after the financial crisis?

\section{Background}

\subsection{Bahrain's Economy}

Bahrain is the first country where oil was discovered and the first that announced that it is draining. Oil Revenues and natural gas currently account for approximately $10 \%$ of its Gross Domestic Product (GDP). Thus, Bahrain has worked to become a financial center in the GCC.

The Kingdom of Bahrain has become a major financial center where many international financial institutions operate both onshore and offshore, without impediments. Currently the financial sector is the largest contributor to GDP at $30 \%$.

Around 370 offshore representative offices and units are located in Bahrain, and 65 American firms. The Kingdom of Bahrain has made a concerted effort to become one of the leading Islamic finance centers in the Arab world, and has standardized regulation for the Islamic banking industry. Currently with its 32 Islamic commercial banks, a range of investment and leasing banks, and Islamic insurance companies (Takaful), Bahrain has the largest concentration of Islamic financial institutions in the Middle East.

Bahrain has worked to develop other industries of service such as information technology industry, healthcare and education.

The government used its oil income to build a top advanced infrastructure in telecommunications and transportation.

The government moved toward privatizing the production of electricity and water by licensing for constructing an independent power plant at a cost of \$500 million. The company started operations in May 2006.

[http://www.traveldocs.com/bh/economy.htm]

Kingdom of Bahrain Financial Sector:

The financial sector in the Kingdom of Bahrain is diversified and well-developed. The sector consists of a variety of both Islamic and conventional financial institutions and markets; the financial sector is well-positioned, offering a wide range of financial products and services which makes Bahrain the leading financial center in the 
GCC. The financial sector represents the largest single employer in Bahrain, with Bahrainis representing over 80\% of the work force.

One of the key drivers of growth in the country is this sector; its contribution is $27 \%$ of Bahrain's GDP.

The Central Bank of Bahrain (CBB) is the main regulator and supervisor of banks in Bahrain, controlling the on-going regulation, licensing and supervision. To qualify for a license the requirements are capital adequacy, business conduct, risk management, disclosure requirements and reporting actions.

[http://www.cbb.gov.bh/cmsrule/default.js]

\subsection{Types of Banks in Bahrain}

Bahrain has attracted many corporations and banks to expand their business and open their branches and subsidiaries in Bahrain.

There are many banks operating in Bahrain under the regulation and supervision of $\mathrm{CBB}$, investment and commercial banks. The Commercial banks are divided into conventional and Islamic banks.

There are also offshore commercial banks which do not offer regular banking services within Bahrain but offer financing for large business and projects.

[http://www.marcopolis.net]

\subsection{Literature Review}

The topic of financial ratios analysis has always been important for both researchers and those involved in finance. Susan W. (2003) stated that lenders often rely on ratio analysis because it allows them to see how one's business is doing and how compare it compares to other businesses which they have loaned money to. The potential loan creditor also requires information about security that the Ratio Analysis can be provided (Hingorani N.L. and A.R. Ramanathan, 1986).

Ratio analysis is a useful tool for business owners as well. It measures the health of the business whether it is a bank or a multinational corporation. It helps to measure the performance of the business, to diagnose potential problems and to see how well it is doing over time (Spathis, K., and Doumpos M., 2002).

The current ratios, total debt ratios, and profit margin ratios are the three important ratios that indicate the health of your business (Susan W., 2003).

Current ratio is an excellent diagnostic tool, because it measures whether or not your business has enough resources to pay its bills over the next 12 months. Total debt ratio shows how much your business is in debt, making it an excellent way to check your business's long-term solvency (Lynch, R. and Willamson, 1983). The profit margin shows how much net profit your business's sales are producing.

Howard Finch (2005) stated that financial ratios are one of the most common tools of managerial decision making. A ratio is to compare one number to another-mathematically, a simple division problem. Financial ratios involve the comparison of various figures from the financial statements in order to gain information about a company's performance. It is the interpretation, rather than the calculation, that makes financial ratios a useful tool for business managers. The future decisions can be evaluated in terms of measuring the behavior of the firm value, given a decision to be analyzed (Chien, T., Danw, S. Z. 2004). However, examining historical financial statements analysis has the limitations in reaching the optimal financial decisions (Ignacio Velez-Pareja, 2007). Ratios may serve as indicators, clues, or red flags regarding not worthy relationships between variables used to measure the firm's performance in terms of profitability, asset utilization, liquidity, leverage, or market valuation (Sree Rama Murthy, Y., 2004).

Nenide et al. (2003) used ratio calculations with multivariate analysis relying on a large database for predicting the performance of business firms.

In their paper, adjustment techniques were recommended for researchers using multivariate statistical analysis on large databases for ratio calculation, so that results of the analysis would be meaningful and that inferences could be drawn from the data. In order to illustrate and explain techniques for data error identification, they used sample data from a Balance Sheet and Income Statement of 250 firms, sampled from the Financial Statement Database of the Kauffman Center for Entrepreneurial Leadership. They were also able to demonstrate how to handle the problem of denominators being negative or approaching zero when calculating ratios, and effective techniques for transforming the data to achieve approximation of normal distributions.

Salmi and Teppo Martikainen (1994) provided a critical review of the theoretical and empirical basis of four central areas of financial ratio analysis. 
The research areas reviewed were the functional form of the financial ratios, distributional characteristics of financial ratios, classification of financial ratios, and the estimation of the internal rate of return from financial statements. A common feature of all these areas of financial ratio analysis seems to be that while significant regularities can be observed, they are not necessarily stable across the different ratios, industries, and time periods. This leaves much space for the development of a more robust theoretical basis and for further empirical research.

Jerome Osteryoung et al. (1992) stated that financial ratios were broadly used by academic researchers, financial analysts, lenders, and small business managers. Most commonly, researchers use ratios as predictor variables in models that forecast business distress and failure. Other common applications include trend analysis studies of individual firm performance and cross-sectional studies that compare individual firm ratios against average industry ratios. These average industry ratios are usually reported for different size firms in each industry, under the assumption that ratios are different for firms of different sizes. (Robert Morris Associates' Annual Statement Studies and the Financial Research Associates' Financial Studies of the Small Business both use size categories in the reporting of financial ratios). They have found evidence that financial ratios differ across different size firms. In their study they examined the differences between the financial ratios of large public and small private firms across a large number of narrowly defined industry groups.

If certain ratios are found to be constant across the different size groups, it would indicate that those ratios could be used for ratio comparison purposes, regardless of whether the ratios are from large or small firms. If the ratios are found to be different, the results will emphasize the importance of identifying the appropriate source of industry and its average ratio for comparison purposes when examining a particular ratio.

A J Singh (2002) in his study identified commonly used ratios in the lodging industry and discovered their importance for lodging financial executives. In his point of view, financial ratios have always been a valuable tool for lodging industry managers. Ratios allow the user to summarize and analyze related data to provide meaningful information for making decisions.

The Operating and Profitability ratios clearly stand out as the most important ratios for lodging managers. This study contributes to educating managers about the range of ratios, their relative importance, and opportunities for using ratios, which were considered less useful in the past.

\section{Methodology}

\subsection{Data Collection}

This study will utilize data collected from secondary sources, which are the annual reports of commercial banks in the Kingdom of Bahrain for the period of 2005-2009.

For purposes of international comparison; data was drawn from various internet based sources local banks and international foreign banks.

\subsection{Population and Sample}

The population in this study includes all 109 Banks in The Kingdom of Bahrain (82 Conventional banks retail and wholesale and 27 Islamic banks).

The sample was drawn from the different types of banks in Bahrain. It was selected to include all types of banks with different categories and the availability of data for the covered period of the study.

Table 1. Sample banks

\begin{tabular}{ll}
\hline Name & Type \\
\hline National Bank of Bahrain & Conventional - Retail (Local) \\
Bank of Bahrain and Kuwait & Conventional - Retail (GCC) \\
Gulf Finance House & Islamic - Wholesale \\
Kuwait Finance House & Islamic - Retail \\
BNP Paribas & Conventional - Wholesale (International) \\
\hline
\end{tabular}

\subsection{Analysis Plan}

A set of financial ratios will be used to measure the performance of the banks by analyzing the relationship 
between independent and dependent variables. By comparing these ratios, the results will be used to measure the effect of the financial crisis on the performance of the banks.

The independent variables are: the size of the bank, the type of bank, and the policies and regulations that the CBB sets which cannot be controlled or changed by the bank.

Dependent variables are: the performance of the bank, the policies and regulations, and internal controls and processes of the banks.

\subsubsection{Definition of Variables}

\section{Profitability Management Ratios}

Profitability reflects the final result of business operations. There are two types of profitability ratios: profit margin ratios and rate of return ratios.

The profit margin ratios show the relationship between profit and revenue. The rate of return ratios reflects the relationship between profit and investment. Some rate of return ratios are: return on assets, earning power, return on capital employed, and return on equity.

Return on Equity (ROE) is calculated by dividing the total profit after tax by total shareholders equity. From the investor's point of view, ROE on a Post - Tax basis is a better measure of profitability. While ROE (post tax) itself is not an indicator of investors return on investment (investors return on investment would rather depend on dividend declared plus capital appreciation if any) we can argue that a higher ROE leads to better return for the shareholders.

Return on Assets (ROA) is another good measure of performance and profitability. However, ROA does not reflect the impact of capital structure decisions (this financial leverage is also called gearing on the firms earnings).

The DuPont model expresses profitability as a percentage of total assets and total shareholders equity. This model is very useful for evaluating how a bank is doing over time.

Dupont Model Profitability Ratios

$\mathrm{ROE}=$ Profit Margin $\times$ Asset Yield $\times$ Leverage

or

ROE $=$ Return on Assets $\times$ Financial Leverage

Profit Margin $=$ Profit after Tax / total income

Return on Assets can be expressed as

ROA $=$ Profit Margin $\times$ Asset Yield

Liquidity Management Ratios

Liquidity refers to the ability of a firm to meet its obligations in the short run, usually one year. Liquidity ratios are generally based on the relationship between current assets and current liabilities.

Liquidity risk management refers to the ability of any banking institution to maintain the right cash balance. The term cash can be explained as currency held with the banks' plus balances with Central Banks of Bahrain.

Profit sub - optimization is possible if a bank is maintaining high level of cash balances. Banks may lose profits if they have an opportunity to invest these funds. Excess cash earns a zero interest. If such cash is invested in the form of commercial loans or securities then the bank would earn a return which directly contributes to the profit. Cash accumulated through the receipt of deposits requires banks to pay interest to the depositors.

Liquidity Management Ratios

Liquid Assets Ratio $=$ Total Cash Resources $/$ Assets * 100

Total Cash Resources $=$ Cash + Treasury Bills + Placements with Banks

Loans to Deposit Ratio $=$ Loans $/$ Deposits * 100

\section{Interest Rate Risk Management Ratios}

Interest rate risk can be defined as the risk, which arises when interest rates are changed. This has a direct impact on the interest earned on loans and investments and the interest paid on deposits (Prasanna Chandra, 2007). Interest rate risk management is required in order to manage the net interest margin, and to control the risk posed by changing interest rates while trying to take advantage of changing interest rates. 
The risk of interest rates changing can be controlled by matching the re-pricing maturities of assets and liabilities. If both the asset and the liability are reprised at the same time, a bank will be able to maintain the net interest margin as interest cost and interest earnings either by going up or down simultaneously.

Interest Rate Risk Management Ratios:

Break Even Yield = Interest Expense as \% Assets*

Interest Yield $=$ Interest Revenue as \% of Assets*

Net Interest Margin $=$ Net Interest Income as \% Assets

(*assets $=$ average asset of current year and previous year)

\section{Results and Interpretation}

Analysis (Profitability ratios)

Table 2. DUPONT model profitability ratios

\begin{tabular}{|c|c|c|c|c|c|c|}
\hline & & 2005 & 2006 & 2007 & 2008 & 2009 \\
\hline \multirow[t]{5}{*}{ BNP } & Return on Equity & $13.67 \%$ & $14.24 \%$ & $13.17 \%$ & $5.85 \%$ & $8.06 \%$ \\
\hline & Profit Margin & $28.76 \%$ & $27.94 \%$ & $25.2 \%$ & $12.60 \%$ & $16.10 \%$ \\
\hline & Asset yield & $1.73 \%$ & $1.94 \%$ & $1.83 \%$ & $1.32 \%$ & $1.95 \%$ \\
\hline & Leverage & 27.35 & 26.27 & 28.52 & 35.20 & 25.61 \\
\hline & Return on assets & $0.50 \%$ & $0.54 \%$ & $0.49 \%$ & $0.16 \%$ & $0.31 \%$ \\
\hline \multirow[t]{5}{*}{ GFH } & Return on Equity & $12.11 \%$ & $31.68 \%$ & $39.03 \%$ & $30.19 \%$ & $(168.09 \%)$ \\
\hline & Profit margin & $62.35 \%$ & $61.20 \%$ & $58.54 \%$ & $47.26 \%$ & $(171.49 \%)$ \\
\hline & Asset Yield & $9.26 \%$ & $23.03 \%$ & $26.12 \%$ & $17.72 \%$ & $3.78 \%$ \\
\hline & Leverage & 2.09 & 2.25 & 2.55 & 3.6 & 3.79 \\
\hline & Return on assets & $5.77 \%$ & $14.09 \%$ & $15.29 \%$ & $8.3 \%$ & $(44.35 \%)$ \\
\hline \multirow[t]{5}{*}{ KFH } & Return on Equity & $22.78 \%$ & $23.19 \%$ & $19.89 \%$ & $11.02 \%$ & $0.90 \%$ \\
\hline & Profit margin & $48.39 \%$ & $54.16 \%$ & $56.96 \%$ & $46.35 \%$ & $5.66 \%$ \\
\hline & Asset Yield & $12.10 \%$ & $9.51 \%$ & $7.8 \%$ & $6.45 \%$ & $4.06 \%$ \\
\hline & Leverage & 3.89 & 4.5 & 4.47 & 3.68 & 3.91 \\
\hline & Return on assets & $5.84 \%$ & $5.15 \%$ & $4.44 \%$ & $2.99 \%$ & $0.23 \%$ \\
\hline \multirow[t]{5}{*}{ NBB } & Return on Equity & $14.00 \%$ & $16.59 \%$ & $17.05 \%$ & $15.98 \%$ & $17.74 \%$ \\
\hline & Profit margin & $62.18 \%$ & $64.05 \%$ & $63.90 \%$ & $55.44 \%$ & $59.24 \%$ \\
\hline & Asset Yield & $3.28 \%$ & $3.43 \%$ & $3.42 \%$ & $3.08 \%$ & $3.41 \%$ \\
\hline & Leverage & 6.87 & 7.55 & 7.80 & 9.36 & 8.77 \\
\hline & Return on assets & $2.04 \%$ & $2.19 \%$ & $2.18 \%$ & $1.70 \%$ & $2.02 \%$ \\
\hline \multirow[t]{5}{*}{ BBK } & Return on Equity & $16.89 \%$ & $17.42 \%$ & $12.61 \%$ & $12.90 \%$ & $15.15 \%$ \\
\hline & Profit margin & $52.39 \%$ & $50.84 \%$ & $34.19 \%$ & $23.55 \%$ & $37.83 \%$ \\
\hline & Asset Yield & $3.73 \%$ & $3.80 \%$ & $4.18 \%$ & $5.3 \%$ & $4.06 \%$ \\
\hline & Leverage & 8.6 & 9.02 & 8.81 & 10.35 & 9.87 \\
\hline & Return on assets & $1.95 \%$ & $1.93 \%$ & $1.4 \%$ & $1.25 \%$ & $1.53 \%$ \\
\hline
\end{tabular}

Profit margins of Bahrain commercial banks have tended to vary from one financial institution to another, for example in the year 2005, GFH reported a profit margin as high as $62.35 \%$ while in the same year BNP reported a PM of only $28.76 \%$.

An analysis of the profit margin ratios of various banks from 2005 to 2009 shows that NBB was successful in managing profit margins even though there was a slight decline trend in 2008 and 2009- this also indicated that NBB was able to control operating costs well. 
Table 3. Profit margin (\%)

\begin{tabular}{llllll}
\hline & $\mathbf{2 0 0 5}$ & $\mathbf{2 0 0 6}$ & $\mathbf{2 0 0 7}$ & $\mathbf{2 0 0 8}$ & $\mathbf{2 0 0 9}$ \\
\hline BBK & 52.39 & 50.84 & 34.19 & 23.55 & 37.83 \\
BNP & 28.76 & 27.94 & 25.20 & 12.60 & 16.10 \\
GFH & 62.35 & 61.20 & 58.54 & 17.26 & $(171.49)$ \\
KFH & 48.39 & 54.16 & 56.96 & 46.35 & 5.66 \\
NBB & 62.18 & 64.05 & 63.90 & 55.44 & 59.24 \\
\hline
\end{tabular}

GFH reported lower PM in 2008 at $17.26 \%$ and it was negative in 2009 at $117.49 \%$. In $2009 \mathrm{KFH}$ reported its lowest PM in 5 years at $5.66 \%$. GFH revenue decreased by $89 \%$ in 2009 compared to 2008 . The huge provision for impairment affected the income of GFH in 2009.

All five banks reported a decline trend in PM in 2008 and 2009 which shows the global financial crisis largely hit the performance of financial institutions of Bahrain.

Asset yields of Bahraini banks during the period of 2005 to 2009, show stability in the case of NBB and BBK, whereas BNP, GFH and KFH reported a decline trend in 2008 and 2009.

Table 4. Asset yield (\%)

\begin{tabular}{|c|c|c|c|c|c|}
\hline & 2005 & 2006 & 2007 & 2008 & 2009 \\
\hline BBK & 3.73 & 3.80 & 4.18 & 5.3 & 4.06 \\
\hline BNP & 1.73 & 1.94 & 1.83 & 1.32 & 1.95 \\
\hline GFH & 9.26 & 23.03 & 26.12 & 17.72 & 3.78 \\
\hline КFH & 12.10 & 9.51 & 7.8 & 6.45 & 4.06 \\
\hline NBB & 3.28 & 3.43 & 3.42 & 3.08 & 3.41 \\
\hline
\end{tabular}

GFH reported its lowest results in 2009 at 3.78\% compared to the previous four years. KFH also reported its lowest results in 2009 at $4.06 \%$ compared to previous years. Only BNP was able to report its highest result in 2009 at $1.95 \%$ compared to previous years. Stability in asset yields can be achieved by adopting good interest rate risk management practices and better asset mix decisions.

Higher leverage improves profitability and cost of equity is high compared to cost of deposits. Therefore, a bank's management would prefer to be high on deposits and low on equity. However, a low equity implies a high leverage ratio, which is risky. A bank with a high leverage ratio (that is low capital to assets ratio) faces the problem of solvency risk) during periods of economic crisis.

Financial Leverage in the five Bahraini Financial Institutions during the period of 2005 to 2009 were in the range of 35.20 times (BNP in year 2008) to 2.09 times (GFH in year 2005). BNP was able to practice stable and high level leverage in 5 years. Only GFH and KFH reported low leverage approximately between 2 to 4 times from 2005 to 2009.

Table 5. Leverage

\begin{tabular}{llllll}
\hline & $\mathbf{2 0 0 5}$ & $\mathbf{2 0 0 6}$ & $\mathbf{2 0 0 7}$ & $\mathbf{2 0 0 8}$ & $\mathbf{2 0 0 9}$ \\
\hline BBK & 8.06 & 9.02 & 8.8 & 10.35 & 9.87 \\
BNP & 27.35 & 26.27 & 28.52 & 35.20 & 25.61 \\
GFH & 2.09 & 2.25 & 2.55 & 3.6 & 3.79 \\
KFH & 3.89 & 4.5 & 4.47 & 3.68 & 3.91 \\
NBB & 6.87 & 7.55 & 7.80 & 9.36 & 8.77 \\
\hline
\end{tabular}


Here, BBK and BNP are showing the leverage ratio more than 8 times, which indicates that the business size of these banks is larger than the other three banks (GFH, KFH and NBB). Income of the Islamic Financial Institutions such as GFH and KFH mostly rely on Murabaha contract fees and profit. These banks mostly depend on the profit sharing rather than interest income.

NBB and BBK are able to generate higher ROE compared to the same level of operational profitability - ROA.

Table 6. Return on assets (\%)

\begin{tabular}{llllll}
\hline & $\mathbf{2 0 0 5}$ & $\mathbf{2 0 0 6}$ & $\mathbf{2 0 0 7}$ & $\mathbf{2 0 0 8}$ & $\mathbf{2 0 0 9}$ \\
\hline BBK & 1.95 & 1.93 & 1.4 & 1.25 & 1.53 \\
BNP & 0.5 & 0.54 & 0.49 & 0.16 & 0.31 \\
GFH & 5.77 & 14.09 & 15.29 & 8.3 & $(44.3)$ \\
KFH & 5.84 & 5.15 & 4.44 & 2.99 & 0.23 \\
NBB & 2.04 & 2.19 & 2.18 & 1.70 & 2.02 \\
\hline
\end{tabular}

Table 7. Return on equity (\%)

\begin{tabular}{llllll}
\hline & $\mathbf{2 0 0 5}$ & $\mathbf{2 0 0 6}$ & $\mathbf{2 0 0 7}$ & $\mathbf{2 0 0 8}$ & $\mathbf{2 0 0 9}$ \\
\hline BBK & 16.89 & 17.42 & 12.61 & 12.90 & 15.15 \\
BNP & 13.67 & 14.24 & 13.17 & 5.85 & 8.06 \\
GFH & 12.11 & 31.68 & 39.03 & 30.19 & -168.0 \\
KFH & 22.78 & 23.19 & 19.89 & 11.02 & 0.90 \\
NBB & 14.00 & 16.59 & 17.05 & 15.98 & 17.74 \\
\hline
\end{tabular}

In 2006, NBB, which had an ROA of $2.19 \%$, reported a ROE of $16.59 \%$. If we agree that shareholders and investors are ultimately interested in return on equity (ROE) then the performance of NBB is better, compared to that of GFH and KFH.

This result can be possible because the average leverage ratio of NBB is 8 times for 5 years in that year as compared to average leverage ratio of GFH and KFH which is 5 and 2.8 for 5 years. BNP and BBK also reported good result in 5 years. However in 2008 and 2009, the figures show a decline trend in return on equity. GFH and KFH reported worst results in 2009 at $168.09 \%$ in the case of GFH and $0.90 \%$ in the case of KFH.

Earnings Per Share is the indicator for the performance of the organization.

Table 8. Earnings Per share (\%)

\begin{tabular}{llllll}
\hline & $\mathbf{2 0 0 5}$ & $\mathbf{2 0 0 6}$ & $\mathbf{2 0 0 7}$ & $\mathbf{2 0 0 8}$ & $\mathbf{2 0 0 9}$ \\
\hline BBK & 0.052 & 0.047 & 0.043 & 0.034 & 0.042 \\
BNP & 7.02 & 8.49 & 8.03 & 2.99 & 5.20 \\
GFH & 136 & 29.92 & 47.55 & 29.08 & -68.41 \\
KFH & NA & NA & NA & NA & NA \\
NBB & 56.6 & 56.9 & 64.10 & 44.7 & 55.10 \\
\hline
\end{tabular}

BBK and BNP are showing stability in their performance in profitability of Earning per Share but GFH suffered losses in 2009 - large provisions against the net profit showing negative earnings per share.

Analysis of ROE trends in the five banking institutions in Bahrain over the period of 2005 to 2009 indicates that years 2005, 2006, and 2007 were good years for these banking institutions in general.

Furthermore, the ratios reported above also show that the good performance in 2005, 2006 and 2007 was mainly due to good profit margins generated by these institutions in those years. Similarly ratios from 2008 and $2009 \mathrm{r}$ 
show that poor profit margins had a significant impact on return in equity in these years.

Asset Interest Yield and leverage variations from year to year have been less important. The conclusion therefore is that, due to economic crisis the performance of Bahrain banks affected severely which forced them to focus on factors influencing profit margins like cost management and credit risk management practices.

Bank BNP prefers a high leverage multiplier at 26\% average for 5 years from 2005 to 2009 while GFH shows lowest leverage at $2.8 \%$ as average for 5 years. In 2008 and 2009 there are no significance changes in leverage and capital to asset ratios compared to previous period.

There were no significant changes in the leverage ratios or capital to assets ratios of banks during this period, as compared to previous years. BNP and KFH experienced a slight reduction of financial leverage ratio, indicating that they are not able to deploy as much assets for every unit of capital in this period. Better leveraging would help banks to improve profitability and reduce spreads.

\section{Analysis (Liquidity Management Ratios)}

The period from 2005 to 2009 , demonstrated that liquidity management ratios for the GFH showed a high level of liquidity. It was reported that this was the worst performance in 2009. Although NBB also reported an average of $27 \%$ liquidity ratio in 5 years, their profit margin was still stable.

Regarding the Loan to Deposit ratio, KFH showed good results in 2008 and 2009 where all other institutions showed below $100 \%$ result. GFH had the lowest result in 2009 at $28.32 \%$.

KFH experienced good results in 2009 at $175 \%$. BNP had a low liquid asset ratio in 2005 at $0.56 \%$ which moved to a higher liquid asset ratio in 2009 to $2.73 \%$. At the same time the bank's loan to deposit ratio declined from $105.87 \%$ in 2006 , to $92.98 \%$ in 2009 . According to the annual reports, companies having a lower level policy of lending, and a higher liquid assets ratio, may be as a result of company liquidity policy. We can conclude that apart from KFH, all other banks showed a decline trend in Loan to Deposit ratio because the financial crisis had depressed the market causing these banks to change their lending policies.

\section{Analysis (Interest Rate Risk Management Ratios)}

Comparisons of the interest rate management ratios from 2005 to 2009 indicate that there was a considerable decline in Asset Interest Yield in 2009. If there had been a decline in Break Even Yield more than the decline of Asset Interest Yield the impact would be an improvement in Net Interest Margins.

The change in Asset Yield, Break Even Yield and Net Interest Margin has to be viewed in the light of a general decline or increase in interest rates in the Bahrain economy. These ratios indicate that banks have been able to manage and overcome the interest rate risk created by declining interest rates. Apart from the effect of the financial crisis, the decline in Break Even Yield shows there is change in the interest risk gap management strategies of Bahraini banks. However, GFH was the only bank showing a negative result in Net Interest Margin in 2009 at a rate of $-0.91 \%$ (Due to huge provisions for Impairment)

KFH recorded the lowest Break Even Yield at $0.69 \%$ in 2009. This Islamic bank mostly depended on the contract fees, investment activities, and shares of income from associates rather than interest income.

All five banks demonstrated a decline in Asset Interest Yield in 2008 and 2009 because of the decline in interest income or profit sharing income (Islamic banks) compared to the amount of assets.

\section{Major Results}

1. Profitability ratios showed an increasing trend in the first three years and a decline trend in 2008 and 2009. GFH suffered huge losses in 2009. (Impact of financial crisis)

2. BBK and BNP achieved a Leverage ratio of more than $8 \%$ and GFH and KFH less than $8 \%$. NBB achieved a ratio higher than $8 \%$ in 2008 and 2009. This indicates that BBK and BNP had the highest share of the market, and highest income from Interest and Fee income. There is an implication that major income depends on profit sharing income, which probably indicates why the Islamic banks show low leverage. (Type of the banks)

3. Asset Interest Yield shows good performance in 2005, 2006 and 2007 but declined in 2008 and 2009. It happened even in the case of Islamic banks GFH and KFH. This shows the performance of assets decreased in 2008 and 2009

\section{Findings as per Research Questions}

1). Difference in the performance measured by Ratios before and after crisis.

The Global financial crisis largely hit the banking activities in the Gulf region. As per the analysis of financial 
performance of five major financial institutions, the financial ratios indicate stable and good performance in 2005, 2006 and 2007, but in most of the ratios showing declining trend in 2008 and 2009.

For example:

Average Profit margin of BBK in 2005, 2006 and 2007 was 52.39\%, 50.84\% and 34.19\% but it declined in 2008 and 2009 to $23.55 \%$ and $37.83 \%$.

BNP recorded $28.76 \%, 27.94 \%$, and $25.20 \%$ in 20052006 and 2007 but declined in 2008 and 2009 to $12.60 \%$ and $16.10 \%$ respectively.

GFH recorded $62.35 \%, 61.20 \%, 58.54 \%$ in 2005,2006 and 2007 but decreased to $17.26 \%$ in 2008 and showed negative ratio (-117.49) in 2009 .

KFH showed $48.39 \%, 54.16 \%$, and $56.96 \%$ in 2005, 2006 and 2007. However, in 2008 and 2009 it declined to $46.35 \%$ and $5.66 \%$ respectively.

NBB showed $62.18 \%, 64.05 \%$, and $63.90 \%$ in 2005,2006 , and 2007 and declined to $55.44 \%$ and $59.24 \%$ in 2008 and 2009.

If profit earning is the main motive for the business of banking, then the above decline trend shows that the recession in market affected the investing and lending transactions of the banks in Bahrain.

It also indicates that the earning per share showed a declining trend in 2008 and 2009 and these are negative in the case of GFH in 2009.

2). Ratios indicate the factors associated with high financial performance Profitability Ratios could be, net profit to total assets, a profit margin, ROI, net profit after taxes to Net worth, Return on Equity, or Return on Assets. The variety of ratios is mainly used to measure the profitability of the business and management's overall effectiveness. The profit of the business is the indicator of the improved financial performance of the organization. If there is decline in profit margin, this also affects the return on equity and return on total assets. GFH showed a profit margin of $(-1171.49 \%)$ which affected the return on assets at $(-44.35 \%)$ and return on equity at (-168.09\%).

These ratios are related to the factors such as cost management, management of interest risk, leverage and liquidity conditions.

3). Relationship between the size of the bank and the ratios applied.

According to the study, ratios, excluding Leverage ratios, are not directly linked to the size of a bank. The profit of a bank cannot be measured according to its size. Even a small bank can achieve high profit and can show highly positive ratios, whilst a bank with a large asset may not yield good income in particular year.

For example, ratios derived from the components of financial statements, showed that GFH's asset size in 2006 was $\$ 1,500,884,000$, and its net profit was $\$ 211,586,000$. But in 2009 the asset size was $\$ 1,642,336,000$ and its net profit decreased to net loss $(\$ 728.379,000)$.

Financial performance of institutions can be affected by the complexity of managing large sized financial transactions. The leverage may be a good position but profitability may show a decline trend due to poor management or due to external factors.

We can conclude that the size of the bank can influence its efficiency in the way it is run, ultimately impacting on the profitability of the firm.

4). The effect of the financial ratio indicators on the future performance management.

These financial ratios are prepared on the basis of historical financial statements and they are useful indicators of a firm's current financial performance and current financial situation. These financial ratios can be used to analyze current trends and to compare the firm's financial position to those of others. They can predict future bankruptcy.

5). Significant difference between ratios applied to Islamic banks compared to the ones used for conventional banks.

In this matter the financial statements of Islamic banks GFH and KFH are do not show interest income, therefore interest rate risk analysis can't be applied to these banks. Thus the ratios that include interest income in the numerator or the denominator should be replaced with income from Murabaha and fees and commissions. Interest expense should be replaced by Profits distributed to depositors' because Islamic banks do not pay interest. Instead, they share their profits with depositors. Some ratios will still be zero or undefined as the 
equivalents for numerators and denominators do not exist for Islamic banks. For instance, a risk ratio, 'Provisions to Earning Assets' will by definition be zero because provisions for loan losses are zero because no loans are made.

\section{Conclusion}

The tools of analysis are helpful in making business decisions, evaluating performance and forecasting future developments (Bhatia, Manohar L. 1986). Control of business activity is crucial for efficiency. Managerial action follows meaningful information flows. These ratios provide a relevant basis, but all ratios may not serve the objective of the control. A profit performance measure, which is widely prevalent, is the Return on Investment, which is considered a primary yardstick for the measurement of operational efficiency. The DuPont chart underlines areas which need managerial control for achieving the basic goal of maximizing the return on capital employed in financial institutions.

This study examined the impact of financial ratios on the financial performance of Bahraini commercial and Islamic banks. The results of the analysis showed that, the financial performance of banks was strongly and positively influenced by their operational efficiency, asset management, and, their size. However, ratios themselves cannot indicate the size of the banks, which means that banks can only be measured by their overall financial performance.

\section{Recommendation}

The Return of Equity (ROE) of the five Bahraini banks has varied much during the period 2005 to 2009.

This study has used the DuPont model to explain the variations in ROE (profitability) through Profit Margin, Asset Yield and Leverage ratios. Analysis of ROE trends in the five Bahraini banks over the period of 2005 to 2009 indicates that years 2005, 2006 and 2007 were on average, good years for the banks. Furthermore, the ratios reported above also show that the good performance in 2005, 2006 and 2007 was mainly due to good profit margins generated by banks in those years. On the other hand in 2008 and 2009, ratios showed that poor profit margins had a significant impact on Return on Equity in these years. Asset Interest Yield and Leverage variations from year to year have been less important.

Banks in the Kingdom of Bahrain should focus on factors such as costs and provisions, which influence profit margins. The decrease in Return on Equity ultimately affects the interests of shareholders. The risk of fluctuations in interest rates penetrates the interest incomes, which affect the overall income of the banks. If the banks increase their income by other means such as free income, profit sharing, investment activities, which have the lowest income expenses, it would increase the overall profitability. KFH shows low rating of breakeven yield ratio compared to other banks.

While most of the banks show a continuous increase in the Liquidity Rate, GFH is still operating in the same environment and within the same regulations, which maintain liquidity levels as high as $77 \%$. Liquid asset ratios of banks have in general increased over the period. High level of liquidity affects the interest revenue therefore banks should have effective liquidity management policies. These policies should maintain adequate cash balances and prevent excess cash balances or deficit cash balances.

Net Interest Margins increased in 2005, 2006 and 2007, even though 2008 and 2009 were not good years in terms of profitability due to the economic crisis. Despite this, we can recommend that the banks should have effective interest rate risk management polices to deal with the effects of fluctuation in interest rates, which can result in lower margins.

A low Leverage ratio indicates that the bank prefers to follow a safe path as it grows, while a high Leverage ratio indicates that the bank is taking more risk. However, a higher Leverage ratio means that the bank chooses to improve its profitability. At the same time, finance experts say that cost of equity is high, compared to the cost of deposits and therefore a bank's management may prefer to finance its asset growth with more deposits and less of capital (equity) resulting in a high Leverage ratio.

In conclusion, the study provides banking authorities with understanding of activities that would enable them to review the financial performance of their bank. The results of this study should provide support in making the right decisions to enhance the financial positions of the bank.

Finally, even though this study has focused on certain ratios, there are many other financial ratios that might be used such Economic Value Added (EVA), as well as other measures of performance that are non-financial such as productivity, customer satisfaction, social responsibility, and the use of technology. 


\section{References}

Annual Report. (2005, 2006, 2007, 2008, 2009). Bank of Bahrain and Kuwait, BNP Paribas, Gulf Finance House, Kuwait Finance House, National Bank of Bahrain.

Bhatia, M. L. (1986). Profit Centers: Concepts, Practices and Perspectives. Somaiya Publications Pvt. Ltd, Mumbai.

Chandra, P. (2007). Financial Management: Theory and Practice. New York: McGraw-Hill. http://highered.mcgraw-hill.com/sites/0070656657

Chien, T., \& Danw, S. Z. (2004). Performance Measurement of Taiwan Commercial Banks. International Journal of Productivity and Performance Management, 53(5), 425-434. http://dx.doi.org/10.1108/17410400410545897

Hingorani, N. L., \& Ramanathan, A. R. (1986). Management Accounting. Sultan Chand: Delhi.

Howard Finch. (2005). Financial Ratios. Retrieved from http://www.referenceforbusiness.com/management/Ex-Gov/Financial-Ratios.htmll\#b

Lynch, R. M., \& Willamson, R. W. (1983). Accounting for Management. New York: McGraw-Hill.

Nenide, B., Pricer, R. W., \& Camp, S. M. (2003). The use of financial ratios for research: problems associated with and recommendations for using large databases. Unpublished manuscript retrieved August 3, 2010 from http://www.fintel.us/download/ProblemswithandRecommendationsforLargeDatabases.pdf.

Osteryoung, J., Constand, R. L., \& Nast, D. (1992). Financial ratios in large public and small private firms. Journal of Small Business Management, 30(3). Available for authorized users in the PDF and HTML formats from Internet: EBSCOhost at FinELib [Cited 5-Oct-2002]. ABI Inform: ProQuest Direct database search keywords used: financial ratio proportionality.

Salmi, \& Martikainen, T. (1994). A Review of the Theoretical and Empirical Basis of Financial Ratio Analysis. The Finnish Journal of Business Economics, 4(94), 426-448. Retrieved from http://lipas.uwasa.fi/ ts/ejre/ejre.html

Singh, A. J., \& Schmidgall, R. S. (2002). Analysis of financial ratios commonly used by US lodging financial executives. Journal of Retail \& Leisure Property, 2, 201-213. http://dx.doi.org/10.1057/palgrave.rlp.5090210

Spathis, K., \& Doumpos, M. (2002). Assessing profitability factors in the Greek banking system: A multi criteria methodology. International transaction in Operational Research, 9, 517.

Sree Rama Murthy, Y. (2004). Financial Ratios of Major Commercial Banks. http://dx.doi.org/10.2139/ssrn.1015238

Ward, S. (2003). Is Your Business Sick? Give Your Business a Health Checkup with These Three Ratios.

Retrieved from http://sbinfocanada.about.com/od/management/a/3ratios.htm 